\title{
Ultra-sensitive detection of papaya ringspot virus using single-tube nested PCR
}

\author{
I. HAMIM, W. BORTH, M. J. MELZER, J. HU*
}

Department of Plant and Environmental Protection Sciences, University of Hawaii at Manoa, 3190 Maile Way, Honolulu, HI-96822, USA

Received September 13, 2017; revised February 28, 2018; accepted September 27, 2018

\begin{abstract}
Summary. - Aphid-transmitted papaya ringspot virus (PRSV) is the greatest disease threat to the commercial production of papaya worldwide. Specific ultrasensitive assays are important for the early detection of PRSV in the field. We have developed a single-tube nested PCR (STNP) assay to address this need. Two nested PCR primer sets were designed to target the P3 gene of PRSV. The annealing temperatures and concentrations of both primer pairs were optimized to reduce potential competition between primer sets in STNP. The assay is more sensitive than regular RT-PCR as determined by serial dilutions of cDNA and RNA templates and sample extracts from infected plants. STNP is capable of detecting PRSV in plants 7 days post-inoculation, whereas RT-PCR and ELISA are capable of detecting PRSV 14 to 21 days post-inoculation. This new assay can also detect PRSV from virus infected but asymptomatic plants. This system could assist epidemiological studies in the field and in quarantine protocols by enabling early detection of very low PRSV infection rates in the field and in imported plant samples.
\end{abstract}

Keywords: early detection; quarantine protocols

\section{Introduction}

Papaya (Carica papaya L.) is a widely grown fruit crop in tropical and subtropical areas that is valued for its nutritional, digestive, and medicinal properties (Manshardt, 1992; Hamim et al., 2014). Several RNA and DNA plant viruses pose a serious threat to papaya production (Tripathi et al., 2008; Maoka et al., 1996; Wang et al., 2013; Chang et al., 2003; Singh-Pant et al., 2012; Yue et al.,2009). Among these, the aphid transmitted papaya ringspot virus (the genus Potyvirus, the family Potyviridae) causes the most widespread, destructive and commercially important disease that results in serious economic and agronomic impacts on papaya production worldwide (Tripathi et al., 2008; Lu et al., 2008; Purciful et al., 1984). PRSV is grouped into two types, PRSV-P and PRSV-W, that are serologically indistinguishable but that have different host specificities. PRSV-P infects papaya and cucurbits, while PRSV-W infects only

${ }^{*}$ Corresponding author. E-mail: johnhu@hawaii.edu; phone: +1-808-258-8189.

Abbreviations: dpi $=$ day(s)-post-inoculation; LAMP $=$ loopmediated isothermal amplification; $\mathrm{PRSV}=$ papaya ringspot virus; STNP = single-tube nested PCR cucurbits (Purciful et al., 1984; Yeh et al., 1984; Chen et al., 2008). PRSV-P causes mosaic, chlorosis, mottling, vein clearing and distortion of the leaves, typical "ringspot" and streaking on fruits, and water-soaked streaks on stems and petioles (Tripathi et al., 2008; Gonsalves et al., 2008). The international trade of papayas threatens commercial papaya production especially with regard to the emergence of new PRSV isolates (Bau et al., 2008; Shen et al., 2014a,b; Tuo et al., 2013). Therefore, the accurate and effective diagnosis of PRSV is crucial for monitoring early infections and minimizing economic losses and the introduction of new PRSV isolates arising from world-wide trade.

Over the past few decades, various diagnostic methods have been developed to detect PRSV including both serological and molecular based methods. ELISA is widely used to detect PRSV, but the sensitivity of this method is less than that of the molecular diagnostic methods - such as PCR, real-time (quantitative) PCR, loop-mediated isothermal amplification (LAMP) and molecular hybridizations (Ling et al., 1991; Chiang et al., 2001; Noa-Carrazanaet al., 2006; Cruz et al., 2009; Shen et al., 2014a,b; Usharaniet al., 2013). However, highly sensitive real-time PCR requires sophisticated and expensive instruments, chemicals and complicated protocols that limit its use by many laboratories in developing 
countries (Shen et al., 2014a,b). A comparatively new and rapid detection assay LAMP requires complex reagents and protocols and also considerable skill in order to use this method reliably. These shortcomings make these molecular assays prohibitive for many laboratories worldwide.

Another very sensitive molecular technique is two-step nested PCR that has been used in laboratories worldwide for sensitive detection of viruses including PRSV (Huo-gen et al., 2000; Jeonget al., 2014). It does not require costly equipment or chemicals like real-time PCR, or the use of complex of protocols like LAMP (Jeonget al., 2014; Dey et al., 2012). However, nested PCR requires the manipulation of previously amplified material and involves the transfer of DNA from one PCR tube to another for the second round PCR raising the risk of cross-contamination (Jeong et al., 2014; Dey et al., 2012; Lin et al., 2010). This potential problem can be overcome by the use of a single-tube nested polymerase chain reaction (STNP) assay capable of reliably detecting very low titer viral targets (Dey et al., 2012).

In the present study, we have developed an ultra-sensitive STNP assay to detect PRSV and compared its sensitivity to regular PCR and ELISA. This new method could be of use by the papaya industry and plant quarantine offices of governments to reliably and sensitively detect very low titers of PRSV.

\section{Materials and Methods}

Sample collection, RNA extraction and cDNA synthesis. PRSVinfected papaya leaves were collected from the island of Oahu in Hawaii, USA (Fig. 1) and used to mechanically inoculate PRSV onto 4-week-old healthy papaya cv. Sunset in greenhouse studies (Tennant et al., 1994). Total cellular RNAs were extracted from systemically infected leaves using the RNeasy plant mini kit (Qiagen, Inc., USA) according to the manufacturer's protocol. RNAs were eluted into $80 \mu \mathrm{l}$ of RNase -free water and stored at $-80^{\circ} \mathrm{C}$ until used. The yield and quality of RNA samples was monitored by electrophoresis in 1\% agarose gels and on a Nanodrop spectrophotometer (Thermo Fisher Scientific, USA). cDNAs were synthesized in reverse transcription (RT) reactions of total RNAs as described previously (Dey et al., 2012) with minor modifications. The reaction mixture consisted of $2 \mu \mathrm{l}$ RNA, $1 \mu \mathrm{l}$ random hexamer primers $(50 \mu \mathrm{g} / \mathrm{ml})$ and $6.5 \mu \mathrm{R}$ RNase-free $\mathrm{H}_{2} \mathrm{O}$. Then reaction was incubated for $10 \mathrm{~min}$ at $72^{\circ} \mathrm{C}$ and quickly chilled on ice. A cocktail of $5 \mu \mathrm{dNTP}$ mixture ( $2.5 \mathrm{mmol} / \mathrm{l}$ each), $4 \mu \mathrm{l} 5 \mathrm{x} \mathrm{MMLV}$ reaction buffer, $1 \mu \mathrm{l} \mathrm{MMLV} \mathrm{reverse}$ transcriptase $(200 \mathrm{U} / \mu \mathrm{l})$ and $0.5 \mu \mathrm{l}$ Rase inhibitor $(40 \mathrm{U} / \mu \mathrm{l})$ was added. The RT reaction was incubated for $10 \mathrm{~min}$ at $25^{\circ} \mathrm{C}$ followed by $50 \mathrm{~min}$ at $42^{\circ} \mathrm{C}$. The products were chilled on ice and stored at $-20^{\circ} \mathrm{C}$ until RT-PCR and STNP reactions were performed.

Primer design. Two nested primer sets (outer and inner) were designed targeting the P3 gene of PRSV using Primer $3^{\circ}$ software (http://frodo.wi. mit.edu/) (Shen et al., 2014a,b; Dey et al., 2012; Lin et al., 2010). In designing the inner primers, a GC content of
$40-50 \%$, a melting temperature $(\mathrm{Tm})$ of $53-57^{\circ} \mathrm{C}$, primer lengths from 18-22 bp, and predicted amplicon sizes from 120-200 bp were considered. In designing, the outer primers, the GC content was similar to that of inner primers, but the melting temperatures were required to be at least $10^{\circ} \mathrm{C}$ higher than the melting temperatures of the inner primers. Lengths for the outer primers were similar to that of the inner primers but primers were chosen to produce amplicon sizes from 300-500 bp (Fig. 2) (Dey et al., 2012; Lin et al., 2010). All of the designed primers were checked for their uniqueness to PRSV against the available microbial and papaya sequences in GenBank for their uniqueness to PRSV (Lin et al., 2010).

Sensitivity of STNP. Sensitivity of the STNP assay was compared to conventional RT-PCR using the inner primer set. cDNAs generated from $130 \mathrm{ng}$ of cellularRNAs were serially-diluted in nuclease free water from $0-10^{7}$-fold and then used as templates. We also evaluated STNP sensitivity using similar RNA dilutions of cellular RNAs extracted from PRSV infected papaya leaves in both assays. Serially diluted RNAs (100 ng-100 fg) were converted into cDNAs and the STNP and RT-PCR assays were performed as described above. The sensitivity of STNP was further compared to results from RT-PCR and ELISA using serial dilutions of extracts from infected papaya leaf tissues (Table 1). ELISA was performed according to the manufacturer's (Agdia, USA) instructions and absorbance of $405 \mathrm{~nm}$ was measured with a Bio-Rad Model 680 microplate reader (BioRad, USA). Absorbance ratios (I/H ratios) of the infected (I) and healthy tissues $(\mathrm{H})$ were calculated from mean values of absorbance for each extract dilution. A positive/negative threshold was set for each plate at two times the absorbance of healthy control $(\mathrm{I} / \mathrm{H}=2)$ for each dilution (Sreenivasulu et al., 2010).

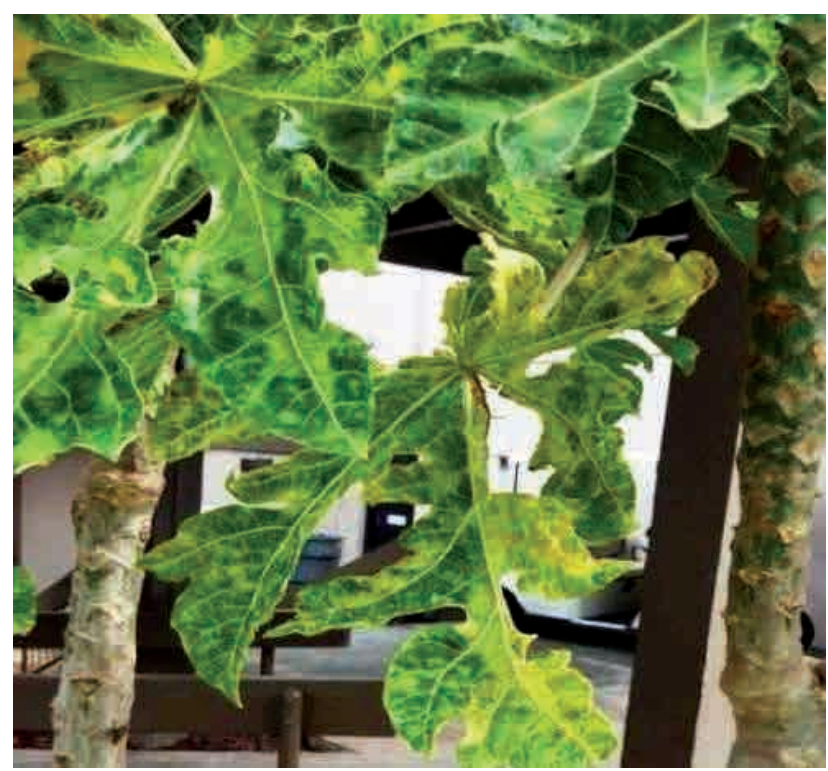

Fig. 1

PRSV-infected papaya samples collected from Island of Oahu, Hawaii 


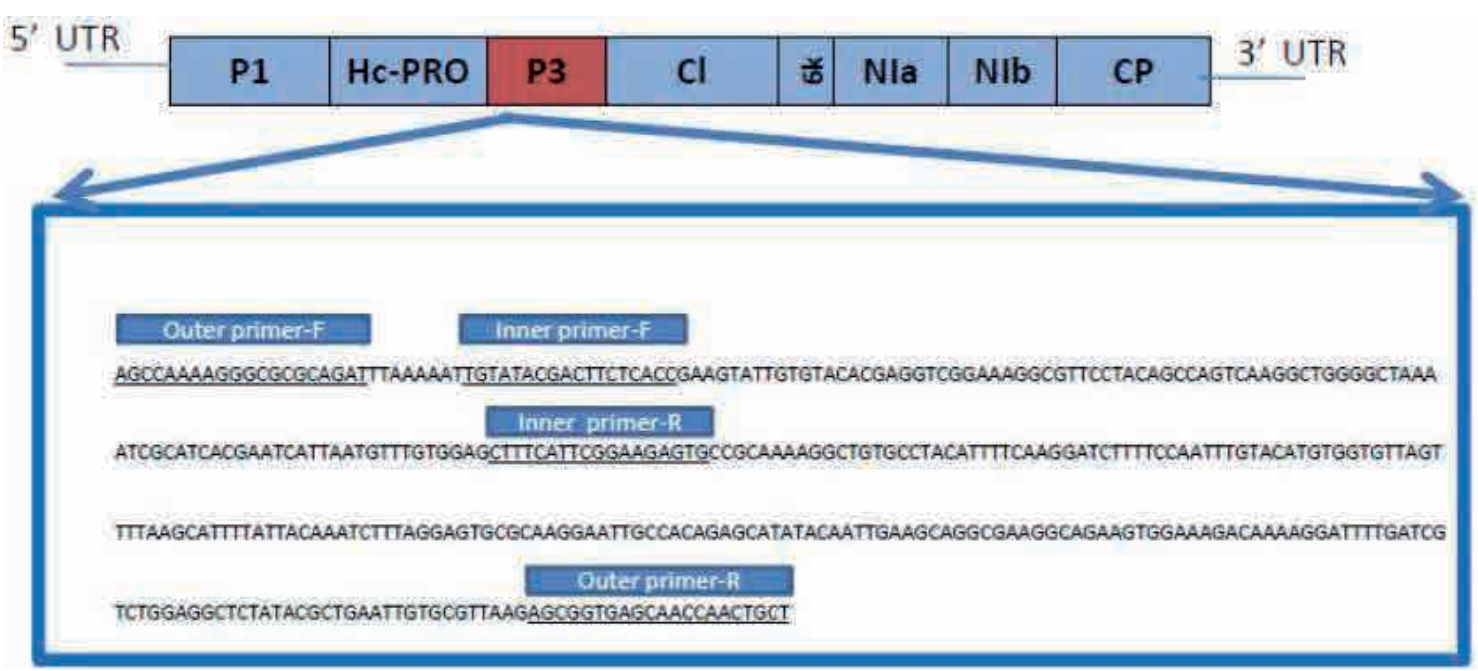

Fig. 2

Primers used in the single tube nested PCR (STNP) assay for the detection for PRSV

F, sense primer; $R$, antisense primer.

Inoculation of papaya plants to monitor PRSV infection. We mechanically inoculated 4-week-old papaya plants of cv. Sunset with PRSV inoculum prepared from PRSV-infected papaya plants. To prepare the virus inoculum, 6-week post inoculation leaves of papaya plants showing PRSV symptoms were ground in 10 volumes ( $\mathrm{vol} / \mathrm{wt})$ of inoculation buffer $(0.01 \mathrm{~mol} / \mathrm{l}$ potassium phosphate, pH 7.4) (Tennant et al., 1994). The inoculum was then applied to the leaves of six papaya plants that had been dusted with carborundum. Leaves with inoculum were gently rubbed with glass rods and then rinsed in $\mathrm{dH}_{2} \mathrm{O}$. Inoculated plants were kept in the greenhouse for symptom development. Young leaves were collected from the inoculated plants at 7-day intervals, beginning 7 days post inoculation (dpi) and continuing until 42 dpi. STNP, RT-PCR and ELISA were used to detect PRSV from the inoculated samples at each time point. This experiment was repeated twice.
Detection of PRSV from symptomatic and asymptomatic samples. A total of 52 papaya leaf samples were collected for diagnosis of PRSV from the island of Oahu. Of these 52 samples, 26 displayed typical PRSV symptoms including mosaic, ring spots, and leaf distortions of leaves, and water soaked streaks on petioles. The remaining samples were asymptomatic. An STNP assay was performed as described above and its detection limits compared to those generated by RT-PCR and ELISA.

\section{Results}

Sensitivity of single-tube nested-PCR (STNP)

The STNP assay was designed based on similar assays reported earlier (Dey et al., 2012; Lin et al., 2010). For the inner
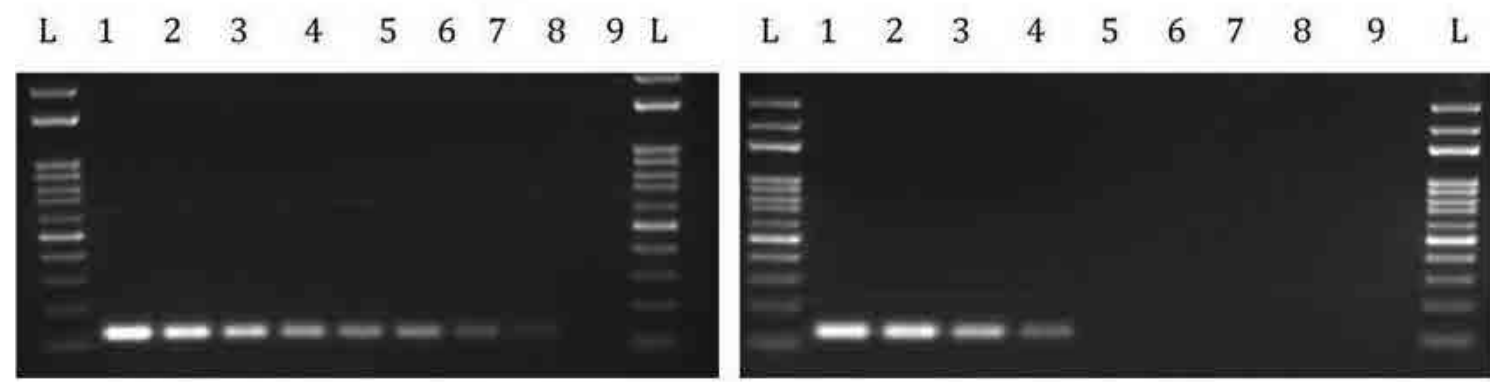

Fig. 3

Sensitivity of STNP (a) and RT-PCR (b) using serially diluted cDNAs prepared from PRSV-infected plant RNA

Lane numbers (1-8) correspond to cDNA dilutions from $0-10^{7}$-fold. Lane 9 is cDNA from healthy control plants. L is the $100 \mathrm{bp}$ ladder. Expected bands are $128 \mathrm{bp}$. 

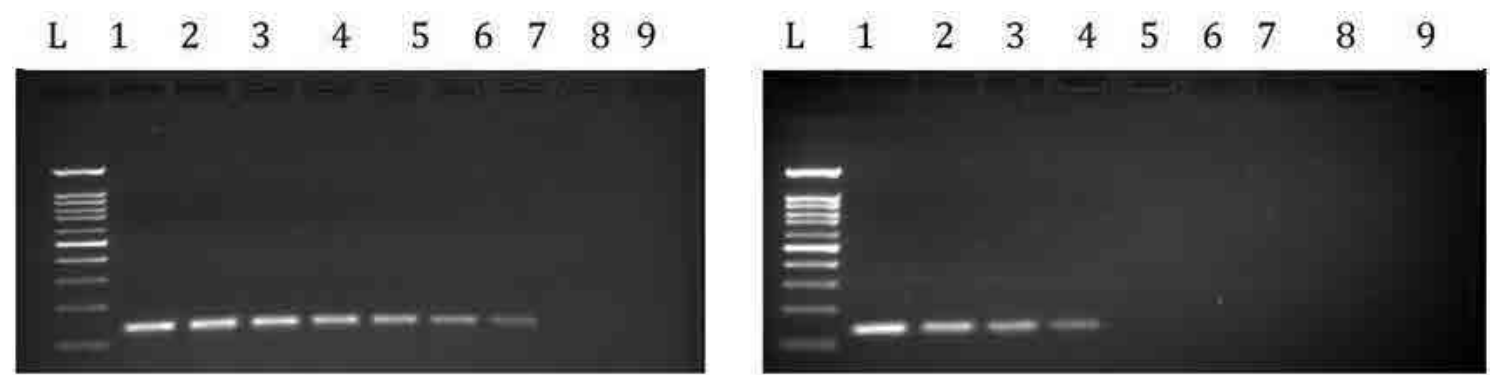

Fig. 4

Sensitivity of STNP (a) and RT-PCR (b) using total RNAs serially diluted from $100 \mathrm{ng}-10 \mathrm{fg}$.

cDNAs were reverse transcribed from diluted total RNAs. Lanes 1-8 correspond to $100 \mathrm{ng}-10 \mathrm{fg}$ of total RNA from papaya leaves. Lane 9 is RNA from healthy control plant. L is $100 \mathrm{bp}$ ladder. Expected band are $128 \mathrm{bp}$.

and outer primers, annealing temperatures were optimized at $55^{\circ} \mathrm{C}$ and $65^{\circ} \mathrm{C}$, respectively. The optimal amounts of the outer and the inner primers were $0.1 \mathrm{pmol}$ and $10 \mathrm{pmol}$, respectively.

The detection limit of the STNP assay was determined in replicated experiments using serially-diluted cDNAs as templates generated from RNAs isolated from PRSV-infected plants. The STNP assay was able to detect cDNA templates diluted up to $10^{7}$-fold, whereas the detection limit of conventional PCR was $10^{3}$-fold, as indicated by the presence of the predicted 128 bp amplicon in gel electrophoresis (Fig. 3).

The sensitivities of the newly developed PRSV specific STNP and RT-PCR assays were also compared using total RNAs serially diluted from 100 ng-10 fg RNA isolated from papaya leaves infected with PRSV. cDNAs were reverse transcribed from diluted total RNAs and used as templates in

Table 1. Comparison of sensitivities of single-tube nested-PCR, ELISA and RT-PCR for the detection of PRSV in serial dilutions of extracts from infected papaya leaf samples

\begin{tabular}{lccc}
\hline Dilution (w/v) & ELISA & RT-PCR & STNP \\
\hline $1: 10$ & $+^{\mathrm{a}}$ & + & + \\
$1: 20$ & + & + & + \\
$1: 40$ & + & + & + \\
$1: 80$ & + & + & + \\
$1: 160$ & + & + & + \\
$1: 320$ & + & + & + \\
$1: 640$ & $-\mathrm{b}$ & + & + \\
$1: 1280$ & - & + & + \\
$1: 2560$ & - & + & + \\
$1: 5120$ & - & + & + \\
$1: 10240$ & - & + & + \\
$1: 20480$ & - & - & + \\
$1: 40960$ & N.T & - & + \\
$1: 81920$ & N.T & - & + \\
\hline
\end{tabular}

${ }^{\mathrm{a} P R S V}$ positive; ${ }^{\mathrm{b}} \mathrm{PRSV}$ negative; ${ }^{\mathrm{c}}$ Not tested.
STNP and conventional PCR. STNP was able to detect the template in concentrations of $100 \mathrm{fg}$ per reaction (Fig. 4a), which was one-thousand fold greater than in RT-PCR, which could detect $100 \mathrm{pg}$ per reaction (Fig. 4b).

The sensitivity of the STNP assay was also compared to the sensitivities of RT-PCR and ELISA assays using serial dilutions of extracts from infected papaya leaf samples (Table 1). The STNP could detect PRSV targets in samples at dilutions of at least 1:81920, whereas PRSV targets could only be detected at dilutions of 1:10,240 and 1:320 by RT-PCR and ELISA respectively (Table 1).

\section{Diagnostic evaluations}

To evaluate the suitability of STNP for routine assays, two independent experiments were conducted comparing it to regular RT-PCR and ELISA. In the first experiment, healthy plants were inoculated with PRSV and young leaves were collected for PRSV detection 7 dpi, 14 dpi, 21 dpi, 28 dpi, $35 \mathrm{dpi}$, and $42 \mathrm{dpi}$ using STNP, RT-PCR and ELISA. STNP proved to be the most sensitive assay, capable of detecting PRSV 7 dpi from 16\% of the PRSV inoculated plants, whereas regular PCR and ELISA could only detect virus in inoculated plants after 14 and 21 days, respectively. At 21 dpi, RT-PCR and STNP were capable of detecting PRSV positive plants in $50 \%$ and $83 \%$ of the inoculated plants, respectively. At $28 \mathrm{dpi}$, PRSV could be detected in 100\%

Table 2. Detection of PRSV by STNP, RT-PCR and ELISA from symptomatic and asymptomatic samples

\begin{tabular}{lccc}
\hline \multirow{2}{*}{ Type of samples } & \multicolumn{3}{c}{$\begin{array}{c}\text { Number of positive samples } \\
\text { (total number of samples tested) }\end{array}$} \\
\cline { 2 - 4 } & ELISA & RT-PCR & STNP \\
\hline symptomatic & $26(26)$ & $26(26)$ & $26(26)$ \\
asymptomatic & $3(26)$ & $12(26)$ & $20(26)$ \\
\hline
\end{tabular}




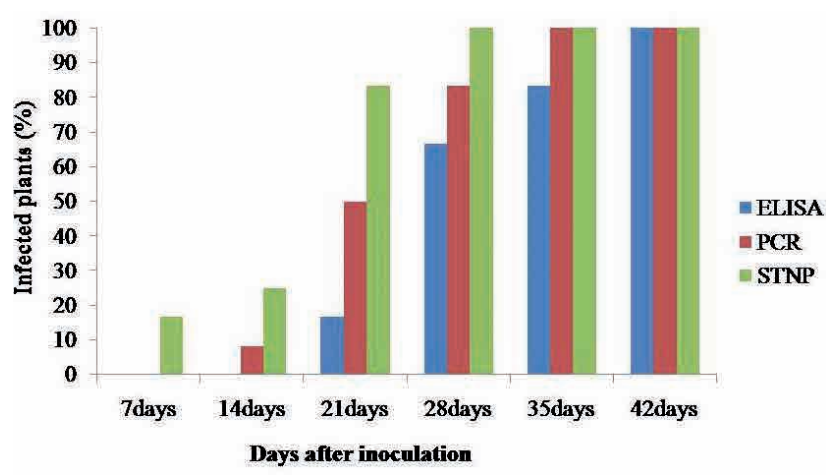

Fig. 5

Comparison of sensitivities of STNP, ELISA and RT-PCR assays for the detection of PRSV infection in inoculated plants

of the inoculated samples using STNP, whereas ELISA and RT-PCR could detect PRSV in $65 \%$ and $80 \%$ of samples, respectively (Fig. 5).

Fifty-two symptomatic and asymptomatic papaya leaf samples were collected on Oahu, Hawaii and assayed for PRSV using STNP, RT-PCR and ELISA. All the symptomatic samples were positive for PRSV by each of these three techniques. However, when asymptomatic plant samples were tested, PRSV could be detected in 20/26 (77\%) using STNP; in 12/26 (46\%) using RT-PCR; and in only $3 / 26$ (12\%) using ELISA (Table 2), confirming that STNP was more robust and sensitive assay.

\section{Discussion}

For decades, serological and molecular methods have been used to detect PRSV in papaya samples collected from the field. The assays currently available to assess PRSV infections can be used to confirm PRSV infection in symptomatic samples (Hamim et al., 2018a). However, most of these assays are not able to consistently detect low levels of PRSV that occur in early stages of infection either in fields or in nurseries (Jeong et al., 2014). In early stages of infection, PRSV occurs in low titers and is unevenly distributed within papaya tissues, often before the development of any symptoms, or with symptoms that may be produced by abiotic stress (Jeonget al. 2014; Hamim personal observation). The early detection of plant viruses and careful monitoring of symptoms are essential to reduce the spread of viruses to new areas or hosts (Jeonget al., 2014; Llop et al., 2000) and therefore, improved methods to detect PRSV with enhanced reliability and sensitivity in asymptomatic samples are crucial.

Nested PCR assays are capable of detecting extremely low titers of PRSV in diseased plants; with much more sensitivity than other molecular and serological methods
(Huo-gen et al., 2000). However, conventional nested PCR, is prone to cross-contamination during manipulation when amplified first-round PCR products are transferred to the second-round PCR (Dey et al., 2012; Llop et al.; 2000). These limitations can be overcome by using STNP assay (Jeong et al., 2014; Dey et al., 2012; Anderson et al., 2003). Llop and colleagues have used STNP assay to detect Erwinia amylovora in infected plants at rates $20 \%$ higher than conventional PCR, and also found that the sensitivity of this assay was comparable to that of nested PCR using sequential reactions.

To improve the detection limits of the PRSV assay and to avoid problems associated with cross-contamination, we have developed an ultra-sensitive STNP assay that has the capability of detecting PRSV with high sensitivity in serially diluted cDNAs, RNAs, and plant extracts. This superior sensitivity was greater than what could be achieved using conventional RT-PCR. Shen et al. (2014b) have developed an RT-LAMP assay capable of detecting PRSV in about 1 pg of total RNA extracted from PRSV infected papaya. This is about 10 -fold less sensitive than our newly developed PRSV STNP assay. Huo-gen et al. (2000) compared the detection of PRSV from PRSV inoculated plants using conventional nested PCR, immunocapture-PCR, ELISA-PCR and ELISA. They found that nested PCR assays were the most sensitive of these techniques, able to detect virus at $3 \mathrm{dpi}$. In our study, STNP was the most sensitive assay evaluated, allowing reliable detection of PRSV at 7 dpi.

This ultrasensitive STNP is capable of detecting low virus titers in asymptomatic PRSV-infected papaya, and could identify PRSV in a higher percentage of field samples than either RT-PCR or ELISA assays.

STNP provides an ultrasensitive and robust method to diagnose PRSV infection. To our knowledge, this is the first report of the use of this methodology to detect potyvirus infections in any plant host. This novel technique eliminates the potential for cross-contamination of samples by eliminating the transfer of amplification products from one PCR tube to another during two-tube nested PCR. This STNP assay is also more sensitive than regular RT-PCR or ELISA, and can detect PRSV in asymptomatic plants. This new robust assay will facilitate epidemiological studies of PRSV and allows the improvement of governments' quarantine systems by allowing the detection of extremely low infection levels of PRSV in papaya from field and other sources. Similar assays could be useful to detect other recently reported important plant viruses in Hawaii and Bangladesh such as dasheen mosaic virus (Wang et al., 2017a, 2018a), taro bacilliform $\mathrm{CH}$ virus (Wang et al., 2017b,c), bean yellow mosaic virus (Wang et al., 2017d, 2018b), pepper mottle virus (Wang et al., 2018c), bean common mosaic virus (Green et al., 2017), banana bunchy top virus (Hamim et al., 2017), tomato leaf curl Bangladesh virus, tomato leaf curl Joydebpur virus and tomato leaf curl New Delhi virus (Hamim et al., 2018b) very 
early in non-symptomatic diseased tissues in various tropical and sub-tropical plant species resulting in more effective disease management strategies (Hamim et al., 2018a).

Acknowledgments. We acknowledge the editorial suggestions of Dr. Gustav Russ and Dr. M. Labudová. This project was supported by the United States Agency for International Development, as part of the Feed the Future initiative, under CGIAR Fund, award number BFS-G-1100002, and the predecessor fund the Food Security and Crisis Mitigation II grant, award number EEM-G-0004-00013 and in part by the USDA- National Institute of Food and Agriculture, Hatch Project HAW9025-H, managed by the College of Tropical Agriculture and Human Resources at University of Hawaii at Manoa, USA.

\section{References}

Anderson TP, Beynon KA, Murdoch DR (2003): Comparison of real-time PCR and conventional hemi-nested PCR for the detection of Bordetella pertussis in nasopharyngeal samples. Clin. Microbiol. Infect. 9, 746-749. https://doi. org/10.1046/j.1469-0691.2003.00601.x

Bau HJ, Kung YJ, Raja JA, Chan SJ, Chen KC, Chen YK, Wu HW, Yeh SD (2008): Potential threat of a new pathotype of Papaya leaf distortion mosaic virus infecting transgenic papaya resistant to Papaya ringspot virus. Phytopathology 98, 848-856. https://doi.org/10.1094/ PHYTO-98-7-0848

Chang LS, Lee YS, Su HJ, Hung TH (2003): First report of Papaya leaf curl virus infecting papaya plants in Taiwan. Plant Dis. 87, 204. https://doi.org/10.1094/PDIS.2003.87.2.204A

Chiang CH, Wang FJ, Jan FJ, Yeh SD, Gonsalves D (2001): Comparative reactions of recombinant papaya ringspot viruses with chimeric coat protein (CP) genes and wild-type viruses on CP-transgenic papaya. J. Gen. Virol. 82, 2827-2836. https://doi.org/10.1099/00221317-82-11-2827

Chen KC, Chiang CH, Raja JA, Liu FL, Tai CH, Yeh SD (2008): A single amino acid of NIaPro of Papaya ringspot virus determines host specificity for infectionof papaya. Mol. Plant Microbe Interact. 21, 1046-1057. https://doi. org/10.1094/MPMI-21-8-1046

Cruz FC, Tanada JM, Elvira PR, Dolores LM, Magdalita PM, Hautea DM, Hautea RA (2009): Detection of mixed virus infection with Papaya ringspot virus (PRSV) in papaya (Carica papaya L.) grown in Luzon, Philippines. Philippine J. Crop Sci. 34, 62-74.

Dey KK, Hong L, Borth WB, Melzer MJ, Hu JS (2012): A highly sensitive single-tube nested PCR assay for the detection of Pineapple mealybug wilt associated virus-2 (PMWaV-2). J. Virol. Methods 183, 215-218. https://doi.org/10.1016/j. jviromet.2012.03.025

Gonsalves D, Suzuki JY, Tripathi S, Ferreira SA (2008): Papaya ringspot virus (Potyviridae). In Mahy BWJ, van Regenmortel MHV (Eds): Encyclopedia of Virology.
Elsevier Ltd., Oxford, pp. 1-8. https://doi.org/10.1016/ B978-012374410-4.00731-7

Green JC, Borth WB, Melzer MJ, Wang YN, Hamim I, Hu JS (2017): First report of Bean common mosaic virus infecting lima bean in Hawaii. Plant Dis. 101, 1557. https://doi. org/10.1094/PDIS-01-17-0125-PDN

Hamim I, Alam, MZ, Ali MA, Ashrafuzzaman M (2014): Incidence of post-harvest fungal diseases of ripe papaya in Mymensingh. Journal of Bangladesh Agricultural University 12, 25-28. https://doi.org/10.3329/jbau.v12i1.21235

Hamim I, Green JC, Borth WB, Melzer MJ, Wang YN, Hu JS (2017): First Report of Banana bunchy top virus in Heliconia spp. on Hawaii. Plant Dis. 101, 2153 https://doi.org/10.1094/ PDIS-02-17-0205-PDN

Hamim I, Borth WB, Marquez J, Green, JC, Melzer, MJ, Hu, JS (2018a): Transgene-mediated resistance to Papaya ringspot virus: challenges and solutions. Phytoparasitica 46, 1-18. https://doi.org/10.1007/s12600-017-0636-4

Hamim I, Borth WB, Melzer MJ, Gonsalves D, Suzuki JY, Wall, MM, Hu, JS (2018b): Molecular analysis indicates that papaya in Bangladesh is a host of multiple begomoviruses. ICPP, Boston, USA. https://apsnet.confex.com/apsnet/ ICPP2018/meetingapp.cgi/Paper/10119

Huo-Gen X, Hu JS, Fan HZ (2000): Detection of papaya ringspot virus by immuno-capture PCR, nested-PCR and ELISAPCR assays. Virologia Sin. 15, 367-372.

Jeong, JJ, Ju HJ, Noh J (2014): A review of detection methods for plant viruses. Res. Plant Dis. 20, 173-181. https://doi. org/10.5423/RPD.2014.20.3.173

Lin H, Chen C, Doddapaneni H, Duan Y, Civerolo EL, Bai X, Zhao $X$ (2010): A new diagnostic system for ultra-sensitive and specific detection and quantification of Candidatus Liberibacter asiaticus, the bacterium associated with citrus Huanglongbing. J. Microbiol. Methods. 81, 17-25. https://doi.org/10.1016/j.mimet.2010.01.014

Ling K, Namba S, Gonsalves C, Slightom JL, Gonsalves D (1991): Protection against detrimental effects of potyvirus infection in transgenic tobacco plants expressing the Papaya ringspot virus coat protein gene. Biotechnology 9, 752-758.

Llop P, Bonaterra A, Penalver J, Lopez MM (2000): Development of a highly sensitive nested PCR procedure using a single closed tube for detection of Erwinia amylovora in asymptomatic plant material. Appl. Environ. Microbiol. 66, 2071-2078. https://doi.org/10.1128/AEM.66.5.20712078.2000

Lu YW, Shen WT, Zho P, Tang JQ, Niu YM, Peng M, Xiong Z (2008): Complete genomic sequence of a Papaya ringspot virus isolate from Hainan Island, China. Arch. Virol. 153, 991-993. https://doi.org/10.1007/s00705-008-0056-3

Maoka T, Kashiwazaki S, Tsuda S, Usugi T, Hibino H (1996): Nucleotide sequence of the capsid protein gene of papaya leaf-distortion mosaic potyvirus. Arch. Virol. 141, 197-204. https://doi.org/10.1007/BF01718601

Manshardt RM (1992): Papaya. In Biotechnology of Perennial Fruit Crops (Biotechnology in Agraculture No. 8); Hammerschlag FA, Litz RE (Eds): CIBA: Wallingford, UK, pp. 489-511. 
Noa-Carrazana JC, González-de-León D, Ruiz-Castro BS, Pi-ero D, Silva-Rosales L (2006): Distribution of Papaya ringspot virus and Papaya mosaic virus in papaya plants (Carica papaya) in Mexico. Plant Dis. 90, 1004-1011 https://doi. org/10.1094/PD-90-1004

Shen W, Tuo D, Yan P, Li X, Zhou P (2014a): Detection of Papaya leaf distortion mosaic virus by reverse-transcription loop-mediated isothermal amplification. J. Virol. Methods 195, 174-179. https://doi.org/10.1016/j.jviromet.2013.09.011

Shen W, Tuo P, Yan X, Li P, Zhou P (2014b): Reverse transcription loop-mediated isothermal amplification assay for rapid detection of Papaya ringspot virus. J. Virol. Methods 204, 93-100. https://doi.org/10.1016/j.jviromet.2014.04.012

Singh-Pant P, Pant P, Mukherjee SK, Mazumdar S (2012): Spatial and temporal diversity of begomoviral complexes in papayas with leaf curl disease. Arch. Virol. 157, 1217-1232. https://doi.org/10.1007/s00705-012-1287-x

Sreenivasulu M, Sai Gopal DVR (2010): Development of recombinant coat protein antibody based IC-RT-PCR and comparison of its sensitivity with other immunoassays for the detection of papaya ringspot virus isolates from India. Plant Pathol. J. 26, 25-31. https://doi.org/10.5423/ PPJ.2010.26.1.025

Tennant PF, Gonsalves C, Ling KS, Fitch M, Manshardt R, Slightom JL, Gonsalves D (1994): Differential protection against Papaya Ringspot Virus isolates in coat protein gene transgenic papaya and classically cross protected papaya. Phytopathology 84, 1359-1366. https://doi.org/10.1094/ Phyto-84-1359

Tripathi S, Suzuki JY, Ferreira SA, Gonsalves D (2008): Papaya ringspot virus-P: Characteristics, pathogenicity, sequence variability and control. Mol. Plant Pathol. 9, 269-280. https://doi.org/10.1111/j.1364-3703.2008.00467.x

Tuo D, Shen W, Yan P, Li C, Gao L, Li X, Li H, Zhou P (2013): Complete genome sequence of an isolate of papaya leaf distortion mosaic virus from commercialized PRSV-resistant transgenic papaya in China. Acta Virol. 57, 452-455. https://doi.org/10.4149/av $2013 \quad 04 \quad 452$

Usharani TR, Laxmi V, Jalali S, Krishnareddy M (2013): Duplex PCR to detect both Papaya ring spot virus and Papaya leaf curl virus simultaneously from naturally infected papaya (Carica papaya L.). Indian J. Biotechnol. 12, 269-272.
Wang Y, Shen W, Wang S, Tuo D, Yan P, Li X, Zhou P (2013): Complete genomic sequence of Papaya mosaic virus isolate from Hainan island. Chin. J. Trop. Crops. 34, 297-300.

Wang YN, Wu B, Borth WB, Hamim I, Green JC, Melzer MJ, Hu JS (2017a): Molecular characterization and distribution of two strains of Dasheen mosaic virus on Taro in Hawaii. Plant Dis. 101, 1980-1989. https://doi.org/10.1094/PDIS04-17-0516-RE

Wang YN, Hu JS, Borth WB, Hamim I, Green JC, Melzer MJ (2017b): First report of Taro bacilliform CH virus (TaBCHV) on Taro (Colocasia esculenta) in Hawaii, U.S.A. Plant Dis. 101, 1334. https://doi.org/10.1094/PDIS-0217-0172-PDN

Wang YN, Borth WB, Green JC, Hamim I, Cao K, Hu JS, Melzer MJ (2017c): Genome characterization and distribution of Taro bacilliform CH virus on taro in Hawaii, USA. Eur. J. Plant Path. 387, 1-5.

Wang D, Hamim I, Borth WB, Melzer MJ, Sun G, Hu JS (2018a): First Report of Dasheen mosaic virus infecting Taro (Colocasia esculenta) in Bangladesh. Plant Dis. https:// doi.org/10.1094/PDIS-03-18-0442-PDN

Wang D, Ocenar J, Hamim I, Borth WB, Fukada M, Melzer MJ, Suzuki J, Wall M, Matsumoto T, Sun G, Ko M, Hu JS (2018b): First report of Bean yellow mosaic virus infecting nasturtium (Tropaeolum majus) in Hawaii. Plant Dis. https://doi.org/10.1094/PDIS-06-18-1082-PDN

Wang D, Hamim I, Borth WB, Melzer MJ, Suzuki J, Wall M, Matsumoto T, Sun G, Hu JS (2018c): First report of Apple of Peru (Nicandra physalodes) naturally infected with Pepper mottle virus in Hawaii. Plant Dis.https://doi. org/10.1094/PDIS-06-18-1061-PDN

Wang YN, Melzer MJ, Borth WB, Green JC, Hamim I, Hu JS (2017d): First Report of Bean yellow mosaic virus in Vanilla in Hawaii. Plant Dis. 101, 1557. https://doi. org/10.1094/PDIS-01-17-0091-PDN

Yeh SD, Gonsalves D, Provvidenti R (1984): Comparative studies on host range and serology of Papaya ringspot virus and Watermelon mosaic virus 1 . Phytopathology 74, 1081-1085. https://doi.org/10.1094/Phyto-74-1081

Yue F, Cui S, Zhang C, Yoon KJ (2009): A multiplex PCR for rapid and simultaneous detection of porcine circovirus type 2, porcine parvovirus, porcine pseudorabies virus, and porcine reproductive and respiratory syndrome virus in clinical specimens. Virus Genes 38, 392-397. https://doi. org/10.1007/s11262-009-0333-6 